\title{
Which anemia is associated with mortality in COVID-19? Mild, moderate or severe?
}

\section{COVID-19'da hangi anemi mortaliteyle ilişkili? Hafif, orta, ciddi?}

\author{
Busra TEZCAN*1 $\square$, Halis Emre CIFTCI $\square$ \\ 'Ministry of Health, Ankara City Hospital, Intensive Care Clinic, Ankara/TURKEY \\ ${ }^{2}$ Ministry of Health, Ankara City Hospital, Neurosurgery Clinic, Ankara/TURKEY
}

\begin{abstract}
Aim: We aimed to investigate the prevalence of anemia at admission to intensive care unit (ICU), association between anemia and mortality, lengths of stay in hospital and ICU (LOS-H and LOS-ICU) in COVID-19 patients.

Material and Methods: We retrospectively analyzed the data of 288 COVID-19 patients who needed ICU admission. Patients were divided into two groups: anemic and nonanemic. Demographic data, labaratory findings at ICU admission, LOS-H and LOS-ICU, mortality were compared between groups. A further classification was made based on hemoglobin levels; severe, moderate and mild anemic patients were analyzed. LOS-H, LOS-ICU and mortality were compared between patients with hemoglobin $>109 \mathrm{~g} / \mathrm{L}$ and $\leq 109 \mathrm{~g} / \mathrm{L}$. Thus; moderate and severe anemic patients were compared to mild anemic and nonanemic patients.
\end{abstract}

Results: Anemia was detected in 137 (47.6\%) patients upon admission to the ICU. Of those; 54 patients (39.4\%) had mild, 76 patients $(55.5 \%)$ had moderate, 7 patients $(5.1 \%)$ had severe anemia. Anemic patients were older, had multiple comorbidities, lower hemoglobin and albumin, higher red cell distribution width (RDW), creatinine and procalcitonin levels. While LOS-H, LOS-ICU and mortality rates did not significantly differ between anemic and nonanemic patients; mortality rate was significantly high in patients with hemoglobin levels $\leq 109 \mathrm{~g} / \mathrm{L}$ (moderate anemic) compared to patients with a hemoglobin level $>109 \mathrm{~g} / \mathrm{L}$ (mild anemic and nonanemic). LOS-H and LOS-ICU were not significantly different between these patient groups. Only seven patients had severe anemia and all of these died.

Conclusion: The results of this retrospective study showed that the anemia prevalence in ICU patients with COVID-19 was high, and mild anemia was not associated with higher mortality rates, while moderate and severe anemia were. Hemoglobin levels of anemic patients with COVID-19 should be closely monitored for timely detecting signs of disease progression.

Keywords: Mild anemia; mortality; intensive care; SARS-CoV-2

Corresponding author*: Busra TEZCAN, Ministry of Health, Ankara City Hospital, Intensive Care Clinic, Ankara/TURKEY

E-mail: busraytezcan@yahoo.com

ORCID: 0000-0001-8914-0234

Recevied: 20.03.2021 accepted: 02.06.2021

Doi: $10.18663 /$ tjcl.922747 


\section{öz}

Amaç: COVID-19 hastalarında yoğun bakım (ICU) kabulü sırasında anemi prevalansını, anemi ile mortalite, hastanede ve yoğun bakımda kalış sürelerinin((LOS-H ve LOC-ICU) ilişkisini araştırmayı amaçladık.

Gereç ve Yöntemler: Yoğun bakım ihtiyacı olan 288 COVID-19 hastasını retrospektif olarak analiz ettik. Hastalar iki gruba ayrıldı: anemikler ve anemik olmayanlar. Grupların demografik verileri, ICU kabulleri sırasındaki labaratuar bulguları, LOS-H ve LOS-ICU ve mortaliteleri kıyaslandı. Hemoglobin düzeyleri temel alınarak ileri bir sınıflama yapıldı; ciddi, orta ve hafif anemik hastalar analiz edildi. LOS-H, LOS-ICU ve mortalite hemoglobin düzeyi $109 \mathrm{~g} / \mathrm{L}$ altındaki ve üstündeki hastalar arasında kıyaslandı. Böylece orta ve ciddi anemik hastalarla hafif anemikler ve anemik olmayanlar karşılaştırıldı.

Bulgular: Yoğun bakım kabulü sırasında 137 hastada $(\% 47,6)$ anemi saptandı. Bunların 54'ünün $(\% 39,4)$ hafif, 76'sının $(\% 55,5)$ orta, 7'sinin $(\% 5,1)$ ağır anemisi vardı. Anemik hastalar daha yaşlı, çoklu komorbiditeye sahip, daha düşük hemoglobin ve albümin, daha yüksek kırmızı küre dağılım genişliği (RDW), kreatinin ve prokalsitonin düzeylerine sahipti. LOS-H , LOS-ICU ve mortalite oranları anemik olan ve olmayan hastalar arasında anlamlı olarak fark göstermezken, hemoglobin düzeyleri $\leq 109 \mathrm{~g} / \mathrm{L}$ hastalarda (orta ve ağır anemikler) mortalite oranları hemoglobin düzeyleri > $109 \mathrm{~g} / \mathrm{L}$ (hafif anemikler ve anemik olmayanlar) göre anlamlı olarak yüksekti. LOS-H ve LOS-ICU bu hasta gruplarında anlamlı fark göstermedi. Sadece yedi hastanın ağır anemisi vardı ve bunların tamamı öldü

Sonuç: Bu çalışmanın sonuçları; yoğun bakımdaki COVID-19 hastalarında anemi prevalansının yüksek ve hafif anemi artmış mortalite ile ilişkili değilken orta ve ağır aneminin artmış mortalite ile ilişkili olduğunu göstermiştir.COVID-19 hastalarında anemik hastaların hemoglobin düzeyleri hastalığın ilerleyişinin erken tespiti için sık monitorize edilmelidir.

Anahtar kelimeler: Hafif anemi,; mortalite; yoğun bakım; SARS-CoV-2

\section{Introduction}

The coronavirus disease 2019 (COVID-19) is an infectious disease caused by the severe acute respiratory syndrome-related coronavirus 2 (SARS-CoV-2) and has been pandemic across the whole world since December 2019. It has, unfortunately, caused a significant burden on social life and all healthcare systems. This pandemic disease is mainly characterized by respiratory symptoms and has different levels of severity frommild upper respiratory disease to severe pneumonia requiring mechanical ventilation and multiorgan failure leading to death [1]. Identification of risk factors that contribute to the development of the severe disease and death is essential to enable risk stratification and optimize hospital resources reallocation. In this regard some researchers studied the assocation between anemia and the severity or mortality of COVID-19 but had controversial results [2-5].

In this study we aimed to investigate the prevalence of anemia at admission to intensive care unit (ICU), association between anemia and mortality, lengths of stay in hospital and ICU (LOS-H and LOS-ICU).

\section{Material and Methods}

\section{Study Population}

We retrospectively analyzed the data of 288 patients with PCR and/or computed tomography (CT) confirmed COVID-19 diseases who needed ICU admission at the Ankara City
Hospital between 1 September,2020 and 31 January,2021. The study was approved by the ethics committee of the Ankara City Hospital. This study was conducted in compliance with the principles of the Declaration of Helsinki. Informed constents were taken from all participants.

\section{Classifications of Anemia}

Anemia was defined according to the World Health Organization (WHO) as hemoglobin $<130 \mathrm{~g} / \mathrm{L}$ in men and hemoglobin $<120$ $\mathrm{g} / \mathrm{L}$ in women. A further classification was made according to the hemoglobin levels; severe anemia, definedas hemoglobin $<80 \mathrm{~g} / \mathrm{L}$, moderate anemia, defined as hemoglobin 80-109 g/L, and mild anemia,defined as hemoglobin 110-129 $\mathrm{g} / \mathrm{L}$ in men and $110-119 \mathrm{~g} / \mathrm{L}$ in women [6].

\section{Outcome Analysis and Measurements}

Data were extracted from the computerized clinical information system of the hospital. Blood samples which were taken from patients at baseline (first hour) were used to analyze.

Patients were divided into two groups; anemic and nonanemic. Demographic data, labaratory findings (hemoglobin, red cell distribution width, platelet, d-dimer, urea, creatinine, albumin, sodium, potassium, ferritin, neutrophil, lymphocyte, neutrophil lymphocyte ratio, C-reactive protein, procalcitonin, interleukin-6), LOS-H, LOS-ICU, deaths were compared between groups. After further classification of anemia, patients 
were divided into two new groups with a hemoglobin cut-off point $109 \mathrm{~g} / \mathrm{L}$. LOS-H, LOS-ICU and mortality were compared between patients with hemoglobin $>109 \mathrm{~g} / \mathrm{L}$ and $\leq 109 \mathrm{~g} / \mathrm{L}$.

\section{Statistical Analysis}

All statistical analyses were carried out using SPSS 20 for Windows (IBM, 2011). Number, percentages, means, standard deviations, medians, and minimum and maximum values were used for descriptive statistics of the study. Demographic comparisons of the two groups were conducted using a chi-square analysis for categorical variables and independent t-tests for continuous variables. The distribution of the data was tested with the Kolmogorov-Smirnoff test. Moreover, skewness and kurtosis were calculated and both should be $<1$ to use parametric tests. Normally distributed data were tested using the parametric Student's t-test and data not normally distributed by the nonparametric Mann-Whitney $U$ test. Two tailed tests were used and $p<0.05$ was regarded as being statistically significant.

\section{Results}

We retrospectively analyzed 288 patients with COVID-19 with a median age of 71 years (27-96 years): 183 men and 105 women. Anemia was detected in 137 (47.6\%) patients upon admission to the ICU. Of those; 54 patients (39.4\%) had mild, 76 patients (55.5\%) had moderate, 7 patients $(5.1 \%)$ has severe anemia.

Anemic patients were older, had multiple comorbidities, lower hemoglobin and albumin, higher red cell distribution width (RDW), creatinine and procalcitonin levels (Table 1). While LOS-H, LOS-ICU and mortality rates did not significantly differ between anemic and nonanemic patients; mortality rate was significantly high in patients with hemoglobin levels $\leq 109 \mathrm{~g} / \mathrm{L}$ (moderate anemic) compared to patients with a hemoglobin level > 109 $\mathrm{g} / \mathrm{L}$ (mild anemic and nonanemic). LOS-H and LOS-ICU were not significantly different between these patient groups (Tablo 2). Only seven patients had severe anemia and all of these died. Because of inadequate sample size (7 to 281), we did not compare LOS-H, LOS-ICU of severe anemic patients and others.

\section{Discussion}

In this study we mainly found that; 1 ) the prevalence of anemia was high (47.6\%) in COVID-19 patients at ICU admission suggesting that anemic patients are more likely to have severe disease , 2) anemia with hemoglobin levels $<130 \mathrm{~g} / \mathrm{L}$ in men and $<120 \mathrm{~g} / \mathrm{L}$ in women is not associated with higher mortality rates, longer LOS-H and LOS-ICU, 3) anemia with a hemoglobin level $<80 \mathrm{~g} / \mathrm{L}$ (moderate and severe anemia) is associated with higher mortality rates in ICU patients.
The WHO has estimated that global prevalence of anemia to be $\sim 24.8 \%$ [7]. This prevalence is variable depending on the population and country studied.Benoit $J \mathrm{~L}$ et al. reported $34.7 \%$ of COVID-19 patients were diagnosed as having anemia at emergency department presentation in USA [8]. However, Dinevari MF et al. evaluated 1274 COVID-19 patients who were hospitalized in Iran and out of whom 615 (48.27\%) were anemic and concluded that this higher prevalence may be related to higher prevalence of pre-existing anemia in İran and higher percentage of the female patients in their study [9]. Bellmann-Weiller et al. reported that $24.7 \%$ of patients with COVID-19 on admission were anemic in Austria [10]. Saydam BK et al. showed an anemia prevalance of $27.8 \%$ in Turkish women in their study [11]. With the facts that males have a higher percentage (63.5\%) in our study population and anemia diagnoses were based on the ICU admission blood samples; the higher anemia prevalence (47.6\%) in our study may be related to the suggestion that anemic patients are more likely to have severe disease $[3,4,10]$.One of the possible explanations for this observation is the negative effects of anemia on immunity, while the other is it increases heart rate, blood pressure and pulmonary capillary leakage by activating sympathetic nervous system and furthermore enables development of acute respiratory distress syndrome (ARDS) $[12,13]$.

While most of the studies focused on the association between anemia and the severity of COVID-19, some also report the association between anemia and mortality of COVID-19 $[3,10,14]$. Bellmann-Weiller et al. reported that anemia, specifically anemia of inflammation is not only associated with longer hospital stays and poor clinical conditions, but also poor survival [10]. Our data also indicate thathemoglobin levels $\leq$ $109 \mathrm{~g} / \mathrm{L}$ (moderate and severe anemia) in COVID-19 patients is associated with higher mortality rates, while mild anemia is not. This may be attributed to impaired tissue oxygenation with this cut-off point of hemoglobin in COVID-19 patients, along with anemia being a reflection of co-morbidities such as impaired renal function or older age or advanced inflammation [15, 16]. Our results support this with significantly older age, higher creatinine, procalcitonin and lower albumin levels of anemic patients. It is also possible that patients who have multiple comorbidities were more likely to be anemic.

RDW is a quantitative measurement of variation in red cell size which increased values indicate anisocytosis. It ranges from approximately $11 \%$ to $15 \%$ in normal subjects. Although it has been widely used as a guide for the differential diagnosis of 


\begin{tabular}{|c|c|c|c|c|}
\hline & $\begin{array}{c}\text { Total } \\
(n=288)\end{array}$ & Patients without anemia $(n=137)$ & Patients with anemia $(n=151)$ & $\mathrm{p}$ \\
\hline Sex(Male) & $183(63.5)$ & $91(66.4)$ & $92(60.9)$ & 0.333 \\
\hline Age & $\begin{array}{c}71 \pm 14 \\
(72 ; 27-96)\end{array}$ & $\begin{array}{c}69 \pm 13 \\
(71 ; 27-95)\end{array}$ & $\begin{array}{c}72 \pm 14 \\
(73 ; 50-96)\end{array}$ & 0.048 \\
\hline $\begin{array}{l}\text { Comorbidities } \\
\text { No } \\
\text { One } \\
\text { Multiple }\end{array}$ & $\begin{array}{c}34(11.8) \\
62(21.5) \\
192(66.7)\end{array}$ & $\begin{array}{l}25(18.2) \\
36(26.3) \\
76(55.5)\end{array}$ & $\begin{array}{c}9(6.0) \\
26(17.2) \\
116(76.8)\end{array}$ & $\begin{array}{l}0.001 \\
0.062 \\
0.000\end{array}$ \\
\hline Hemoglobin & $\begin{array}{c}12.3 \pm 2.3 \\
(12.4 ; 6.9-18.0)\end{array}$ & $\begin{array}{c}14.3 \pm 1.2 \\
(14.2 ; 12.0-18.0)\end{array}$ & $\begin{array}{c}10.6 \pm 1.6 \\
(10.9 ; 6.9-12.9)\end{array}$ & 0.000 \\
\hline RDW & $\begin{array}{c}14.8 \pm 1.9 \\
(14.5 ; 5.0-25.0)\end{array}$ & $\begin{array}{c}14.1 \pm 1.21 \\
(15.1 ; 11.9-18.9)\end{array}$ & $\begin{array}{c}15.4 \pm 2.1 \\
(15.1 ; 5.0-25.0)\end{array}$ & 0.000 \\
\hline Platelet & $\begin{array}{c}244 \pm 111 \\
(224 ; 7-600)\end{array}$ & $\begin{array}{c}251 \pm 104 \\
(228 ; 72-586)\end{array}$ & $\begin{array}{c}238 \pm 118 \\
(221 ; 7-600)\end{array}$ & 0.259 \\
\hline d-dimer & $\begin{array}{c}4.2 \pm 7.7 \\
(1.6 ; 0.2-41.0)\end{array}$ & $\begin{array}{c}3.9 \pm 8.0 \\
(1.4 ; 0.2-41)\end{array}$ & $\begin{array}{c}4.4 \pm 7.4 \\
(1.7 ; 0.2-41)\end{array}$ & 0.137 \\
\hline Urea & $\begin{array}{c}69 \pm 46 \\
(60 ; 11-347)\end{array}$ & $\begin{array}{c}61 \pm 34 \\
(60 ; 12-240)\end{array}$ & $\begin{array}{c}74 \pm 53 \\
(60 ; 11-347)\end{array}$ & 0.057 \\
\hline Creatinine & $\begin{array}{c}1.31 \pm 1.30 \\
(0.91 ; 0.27-9.93)\end{array}$ & $\begin{array}{c}1.05 \pm 0.64 \\
(0.89 ; 0.36-4.65)\end{array}$ & $\begin{array}{c}1.53 \pm 1.66 \\
(1.05 ; 0.27-9.93)\end{array}$ & 0.002 \\
\hline Albumin & $\begin{array}{c}33.6 \pm 5.9 \\
(34.0 ; 3-52)\end{array}$ & $\begin{array}{c}35.5 \pm 5.4 \\
(35.0 ; 3-52)\end{array}$ & $\begin{array}{c}31.8 \pm 5.7 \\
(32.0 ; 17-46)\end{array}$ & 0.000 \\
\hline Sodium & $\begin{array}{c}139 \pm 7 \\
(138 ; 119-185)\end{array}$ & $\begin{array}{c}139 \pm 8 \\
(138 ; 121-185)\end{array}$ & $\begin{array}{c}139 \pm 7 \\
(138 ; 119-168)\end{array}$ & 0.578 \\
\hline Potassium & $\begin{array}{c}4.3 \pm 0.7 \\
(4.2 ; 2.6-6.7)\end{array}$ & $\begin{array}{c}4.7 \pm 0.62 \\
(4.2 ; 3.0-6.4)\end{array}$ & $\begin{array}{c}4.2 \pm 0.7 \\
(4.2 ; 2.6-6.7)\end{array}$ & 0.688 \\
\hline Ferritin & $\begin{array}{c}940 \pm 1626 \\
(596 ; 12-21726)\end{array}$ & $\begin{array}{c}858 \pm 865 \\
(643 ; 14-7583)\end{array}$ & $\begin{array}{c}1015 \pm 2090 \\
(514 ; 12-21726)\end{array}$ & 0.416 \\
\hline Neutrophil & $\begin{array}{c}8.6 \pm 6.1 \\
(7.9 ; 0.1-72.6)\end{array}$ & $\begin{array}{c}9.4 \pm 4.7 \\
(8.6 ; 1.4-24.5)\end{array}$ & $\begin{array}{c}8.4 \pm 7.2 \\
(7.4 ; 0.1-72.6)\end{array}$ & 0.177 \\
\hline Lymphocyte & $\begin{array}{c}0.82 \pm 0.82 \\
(0.60 ; 0.05-7.00)\end{array}$ & $\begin{array}{c}0.79 \pm 0.65 \\
(0.60 ; 0.15-5.50)\end{array}$ & $\begin{array}{c}0.85 \pm 0.95 \\
0.60 ; 0.05-7.00)\end{array}$ & 0.357 \\
\hline NLR & $\begin{array}{c}16.3 \pm 14.2 \\
(12.9 ; 0.4-106.9)\end{array}$ & $\begin{array}{c}17.0 \pm 13.5 \\
(13.6 ; 1.1-83.6)\end{array}$ & $\begin{array}{c}15.6 \pm 14.8 \\
(12.2 ; 0.4-106.9)\end{array}$ & 0.456 \\
\hline CRP & $\begin{array}{c}9.9 \pm 38.4 \\
(0.1 ; 0.0-232)\end{array}$ & $\begin{array}{c}6.9 \pm 28.2 \\
(0.2 ; 0.1-144.0)\end{array}$ & $\begin{array}{c}12.1 \pm 44.6 \\
(0.1 ; 0.0-232)\end{array}$ & 0.375 \\
\hline Procalcitonin & $\begin{array}{c}2.1 \pm 8.8 \\
(0.2 ; 0.0-93.0)\end{array}$ & $\begin{array}{c}1.4 \pm 5.6 \\
0.2 ; 0.0-45.6)\end{array}$ & $\begin{array}{c}2.8 \pm 10.9 \\
(0.4 ; 0.0-93.0)\end{array}$ & 0.000 \\
\hline Interleukin-6 & $\begin{array}{c}206.3 \pm 851.4 \\
(46.1 ; 1.0-10489)\end{array}$ & $\begin{array}{c}170.7 \pm 546.9 \\
(46.6 ; 1-5047)\end{array}$ & $\begin{array}{c}236.1 \pm 1041.8 \\
(44.7 ; 1.0-10489)\end{array}$ & 0.608 \\
\hline Length of stay (ICU) & $\begin{array}{c}11 \pm 10 \\
(8 ; 1-93)\end{array}$ & $\begin{array}{c}10 \pm 8 \\
(8 ; 1-40)\end{array}$ & $\begin{array}{c}11 \pm 12 \\
(8 ; 1-93)\end{array}$ & 0.719 \\
\hline Length of stay (Hospital) & $\begin{array}{c}14 \pm 12 \\
(11 ; 1-100)\end{array}$ & $\begin{array}{c}14 \pm 11 \\
(12 ; 1-100)\end{array}$ & $\begin{array}{c}14 \pm 13 \\
(10 ; 1-93)\end{array}$ & 0.660 \\
\hline Mortality & $186(64.6)$ & $87(63.5)$ & $99(65.6)$ & 0.715 \\
\hline
\end{tabular}

Values are shown as number (percentage) or mean \pm standard deviation (median; minimum-maximum). Significant values marked in bold Abbreviations:RDW;red cell distribution width, NLR; neutrophil lymphocyte ratio, CRP; C-reactive protein, ICU; intensive care unit

\begin{tabular}{|c|c|c|c|}
\hline & $\begin{array}{l}\text { Patients with hemoglobin }>109 \mathrm{~g} / \mathrm{L} \\
\qquad(\mathrm{n}=212)\end{array}$ & $\begin{array}{l}\text { Patients with hemoglobin } \leq 109 \mathrm{~g} / \mathrm{L} \\
\qquad(\mathrm{n}=76)\end{array}$ & $p$ \\
\hline $\begin{array}{l}\text { Length of stay } \\
\text { (ICU) }\end{array}$ & $\begin{array}{c}10 \pm 8 \\
(9 ; 1-40)\end{array}$ & $\begin{array}{c}12 \pm 16 \\
(8 ; 1-93)\end{array}$ & 0.281 \\
\hline $\begin{array}{l}\text { Length of stay } \\
\text { (Hospital) }\end{array}$ & $\begin{array}{c}14 \pm 11 \\
(12 ; 1-100)\end{array}$ & $\begin{array}{c}14 \pm 15 \\
(8 ; 1-93)\end{array}$ & 0.089 \\
\hline Mortality & $129(60.8)$ & $57(75.0)$ & 0.027 \\
\hline
\end{tabular}

Values are shown as number (percentage) or mean \pm standard deviation (median; minimum-maximum). Significant values marked in bold Abbreviations: ICU; intensive care unit 
anemia, with high values found in iron deficiency;an increased RDWmainly reflects a profound deregulation of erythrocyte homeostasisinvolving both impaired erythropoiesis and abnormal erythrocyte metabolism and survival. These may be caused by avariety of abnormalities, like dyslipidemia, aging, oxidative stress, inflammation, erythrocyte fragmentation, poor nutritional status, hypertension, shortening of telomeresandabnormality of erythropoietin function $[17,18]$. The significantly higher values of RDW in anemic COVID-19 patients compared to nonanemic COVID-19 patients can be a result of older age, multiple comorbidities or any other factors above which needs further evaluation.

\section{Study Limitations}

This was a retrospective observational analysis of COVID-19 patients with the need for ICU admission in the region of Ankaraas a regionalreferral center for COVID-19, which might limit thegeneralizability of results. As it is in the nature of a retrospective analysis, these results donot prove any causality.Second, we definedanemia based on the levels of hemoglobin on ICU admission, and we hadno information on the hemoglobin levels before infection and dynamic Hb levels during ICU stay. Third, we did notmeasure other biomarkers of anemia, including serum iron and transferrin levels.

\section{Conclusion}

The results of this retrospective study showed that the anemia prevalence in ICU patients with COVID-19 was high and anemia was not associated with higher mortality rates if dignosed with a hemoglobin cut-off point $<130 \mathrm{~g} / \mathrm{L}$ in men and hemoglobin $<120 \mathrm{~g} / \mathrm{L}$ in women. Furthermore it was associated with higher mortality if mild anemics were considered as nonanemic, based on a cut-off point of $109 \mathrm{~g} / \mathrm{L}$ for hemoglobin. Hemoglobin levels of anemic patients with COVID-19 should be closely monitored for timely detecting signs of disease progression.

\section{Declaration of conflict of interest}

The authors received no financial support for the research and/ or authorship of this article. There is no conflict of interest

\section{References}

1. Madabhavi I, Sarkar M, Kadakol N. COVID-19: a review. Monaldi Arch Chest Dis 2020; 90: 248-58.

2. Cecconi M, Piovani D, Brunetta $E$ et al. Early predictors of clinical deterioration in a cohort of 239 patients hospitalized for Covid-19 infection in Lombardy, Italy. J Clin Med 2020; 9: 1548.

3. Guan W-j, Ni Z-y, Hu Y et al. Clinical characteristics of coronavirus disease 2019 in China. N Engl J Med 2020; 382: 1708-20.
4. Young B, Ong S, Kalimuddin S et al. Singapore Novel Coronavirus Outbreak Research T. EpidemiologicFeatures and Clinical Course of Patients Infected With SARS-CoV-2 in Singapore. JAMA 2020; 323: 1488-94.

5. Yang $X, Y u Y, X u$ J et al. Clinical course and outcomes of critically ill patients with SARS-CoV-2 pneumonia inWuhan, China: a singlecentered, retrospective, observational study. Lancet Respir Med 2020; 8: 475-81.

6. World Health Organization. Haemoglobin Concentrations for the Diagnosis of Anaemia and Assessment of Severity; World Health Organization: Geneva, Switzerland, 2011.

7. McLean E, Cogswell M, Egli I, Wojdyla D, de Benoist B. Worldwide prevalence of anaemia, WHO Vitamin and mineral nutrition information system, 1993-2005. Public Health Nutr 2009; 12: 444-54.

8. Benoit JL, Benoit SW, de Oliveira MHS, Lippi G, Henry BM. Anemia and COVID-19: A prospective perspective. J Med Virol 2021; 93: 708-11.

9. Dinevari MF, Somi MH, Majd ES, Farhangi MA, Nikniaz Z. Anemia predicts poor outcomes of COVID-19 in hospitalized patients: a prospective study in Iran. BMC Infect Dis 2021; 21: 170.

10. Bellmann-Weiler R, Lanser $L$, Barket $R$, et al. Prevalence and predictive value of Anemia and Dysregulated Iron homeostasis in patients with COVID-19 infection. J Clin Med 2020; 9: 2429.

11. Saydam BK, Genc RE, Sarac F, Turfan EC. Prevalence of anemia and related factors among women in Turkey . Pak J Med Sci 2017; 33: 433-8.

12. Ryan AS. Iron-deficiency anemia in infant development: implications for growth, cognitive development, resistance to infection, and iron supplementation. Am J Phys Anthropol 1997; 104: 25-62.

13. Cure $E$, Cure MC. Angiotensin-converting enzyme inhibitors and angiotensin receptor blockers may be harmful in patients with diabetes during COVID19 pandemic. Diabetes Metab Synd. 2020.

14. Hariyanto TI, Kurniawan A.Anemia is associated with severe coronavirus disease 2019 (COVID-19) infection.Transfus Apher Sci 2020; 59: 102926.

15. Weiss, G, Ganz, T. Goodnough, L.T. Anemia of inflammation. Blood 2019; 133: 40-50.

16. Stauder, R, Valent, P, Theurl, I. Anemia at older age: Etiologies, clinical implications, and management.Blood 2018; 131: 505-14.

17. Lippi G, Salvagno G, Guidi G. Red Blood Cell Width is significantly associated with aging and gender. Clin Chem Lab Med. 2014; 52: 197-9.

18. Salvagno GL, Sanchis-Gomar F, Picanza A, Lippi G. Red blood cell distribution width: A simple parameter with multiple clinical applications. Crit Rev Clin Lab Sci 2015; 52: 86-105 